\section{BIRDS OF SURINAM}

\section{Birds of Surinam}

By F. Haverschmidt. Illustrated by Paul Barruel. Pp. xxix $+445+70$ plates. (Oliver and Boyd: Edinburgh and London, 1968.) 252s.

THE author of this sumptuous volume is a well known ornithologist who has now retired to the Netherlands from the post of Chief Justice in Surinam. Here he summarizes what he has learnt about the birds of that little-worked country during more than twenty years of service. His account is based largely on first-hand knowledge, and in drawing on such other sources as there are he has on principle refrained from using extralimital information about the included species (except for terse indications of total range).

Only a few parts of South America, richest continent of all in its birdlife, are as yet covered by comprehensive and up to date ornithological publications. There was thus a need for this book, although the present state of knowledge leaves many gaps to be filled. According to the author, there are at least 100 species that one would expect to find in Surinam but that have not yet been recorded there; and of the 542 species already known, other than as migratory visitors, breeding data are so far only available for 234. Even on these aspects alone there is therefore much to be done by future observers, for whom an invaluable baseline is here provided.

No native species is known to desert Surinam for any part of the year, but local wanderings are common and there are occasional irregular movements. In addition, 60 species of migrants are visitors to the country, mostly from the north and predominantly waders; a very few are visitors from the south, subspecifically distinct from the resident birds.

The book opens with very brief general sections on topography, climate, ornithological history, breeding, migration, future research and conservation. The subsequent treatment of each species is under the heads, as far as applicable, of identification, habitat and habits, nesting, recorded food and range. The author has collected about 8,700 skins (537 species), now mostly in Leiden Museum, and his identification particulars include the colours of the "soft parts", length of wing and body weight.

Most of the species are finely illustrated either in colour or in line. There are photographs of typical habitats and of some nests and nestlings; there is also a map.

Landsborough Thomson

\section{OBITUARIES}

\section{Professor Otto Hahn}

The death of Professor Hahn on July 28 has removed the doyen from the circle of classical radiochemists. Hahn was born in Frankfurt in March 1879; at secondary school he was already attracted to chemical science. He studied in Marburg, was awarded a PhD for his thesis on bromoeugcnol and became an assistant to Professor Zincke with the duty to prepare demonstrations for the professor's lectures. During this period he was offered a post in a chemical firm, Kalle and Co., provided he spent some time first in England to learn the language. Professor Zincke wrote to Sir William Ramsey, and Hahn was given laboratory space in the Chemistry Department of University College, London. Sir William suggested to the visitor he extract the radium contained in a sample of barium bromide by fractional crystallization. Hahn soon noticed that the decay curve of the emanation showed a contribution of the short living thoron. He was able to extract the thorium contamination which was responsible for the thoron. As the discoverer of this new nucleide he was entitled to name it: radiothorium.

Hahn was keen to learn more in this new field; Rutherford's laboratory in Montreal was the place to do so. On the basis of his discovery of radiothorium Rutherford accepted him. In the autumn of 1905 with his Rd-Th and a specimen containing actinium, both presents from Sir William, he went to Montreal. During the nine month period there he discovered radioactinium and $\mathrm{ThC}^{\prime}$. During the summer of 1906 Hahn returned to Germany under Professor Emil Fischer (the famous organic chemist and director of the University Chemical Laboratory of the University of Berlin), who accommodated him in the institute's carpenter shop (1906-12). There Hahn found mesothorium, estimated its half-life and just missed the discovery of the parent of radium, ionium, which was found by Boltwood in the United States.

In 1907 a young lady physicist, Liese Meitner, joined the group provisionally for a period of two years which, however, was extended to thirty years. One of their investigations (with $\mathrm{O} . \mathrm{V}$. Bayer) concerned the energy distribution of electrons emitted in beta decay. They used a simple magnetic spectrometer and discovered distinct lines; later studies showed that the lines were due to internal conversion and not to disintegration electrons.

In 1912 the Kaiser-William Institute for chemistry was built with a small independent department for Hahn. In this non-contaminated laboratory very weak activities such as the beta rays from $K$ and $R b$ could be examined. From the decay constant of $\mathrm{Rb}$ and the $\mathrm{Sr}$ assay of a sample of $\mathrm{Rb}$ mica he was able to calculate the age of the mineral (see Hahn: "Was lehrt uns die Radioaktivität über die Geschichte de Erde").

The still uneertain origin of actinium was attacked by extracting from pitchblende a fraction following tantalum as carrier which was found to produce actinium emanation on decay. Hahn and Meitner named it protactinium. Under the supervision of Hahn the Radiumfabrik in Joachimstal was able to extract $0.5 \mathrm{~g}$ of $\mathrm{Pa}$ from five tons of pitchblende residue.

In 1921 Hahn made the remarkable discovery of uranium $\mathrm{Z}$ which has the same mass and charge as $\mathrm{UX}_{2}$ but different radiative properties. Historically, this is the first case of nuclear isomerism. Only after the discovery of artificial radioactivity in 1939 were new cases of isomerism found; they are of considerable importance for the knowledge of nuclear structure.

Nothing has been said of the many methods developed by Hahn and his collaborators to use radioactivity as a tool to solve many chemical and physical problems. His book Applied Radioactivity contains much information of this kind.

A most exciting and exasperating period started for Hahn when Fermi and his collaborators published results on the irradiation of uranium with slow neutrons. The latter were known to be the most effective agents to induce radioactivity in almost any nucleus. In contrast the case of uranium was most complex: many different activities were observed in bodies with widely varying chemical properties: roughly they behaved as alkalis, alkaline earths, rare earths, heavy metals or rare gases. Those which followed barium when $\mathrm{Ba}$ was used as carrier in precipitation were labelled Eka barium where the Eka referred to the next higher period of the periodic system (not actually known). The formation of the series resembling noble metals was understandable as it was believed at the time that the sequence of elements following uranium would have metallic properties. The existence of radioactive chains was experimentally cstablished; for example: $\mathrm{U}+\mathrm{n} \rightarrow$ Eka $\mathrm{Re} \stackrel{\beta}{\rightarrow}$ Eka Os $\stackrel{\beta}{\rightarrow}$


a stepwise increase of the nuclear charge from 92 for $U$ to 97 for Eka Au. Because similar parallel chains involving 
the same nuclei, but with different half-lives, were observed, one was compelled to assume that isomeric states were propagated along the chain. It seemed unavoidable to regard this as anything but the formation of the transuranium elements, because no nuclear process could be imagined by which much lighter nuclei could be produced on interaction of $\mathrm{U}$ with neutrons. Hahn and Strassmann, however, made the following observation. If a mixture of barium and mesothorium bromide (radium isotope) were fractionated by crystallization, the mesothorium was found to accumulate in the end fraction, while a similar test made with barium and Eka-barium mixture left the latter evenly distributed among the various fractions (a similar result was obtained by I. Curie and P. Savitch in the case of Eka-lanthanum). Hahn and Strassmann pursucd this method with all possible means, taking the greatest care to eliminate any possible errors. In 1939 they published a paper entitled "Nachweis der Entstehung aktiver Bariumisotope aus Uran und Thorium durch Neutronenbestrahlung" with the subtitle "Endgültiger Beweis für das Entstehen von Barium aus dem Uran". On this basis Frisch and Meitner could make their proposal that the uranium nucleus splits. More than four years elapsed before the question of the chemical nature of the irradiation products of uranium was settled. For their persistent and meticulous effort Hahn and Strassmann were awarded the Nobel Prize for chemistry in 1944 .

\section{CORRESPONDENCE}

\section{Who Does What ?}

SIR,--Your correspondent (Nature, 219, 783; 1968), in pointing out the usefulness of the British publication, Scientific Research in British Universities and Colleges, 1967-68, directs attention to certain inconsistencies and irritations, such as deficiencies of the subject index. This publication would lend itself to a computer-based operation and, if certain contributors could be persuaded to write more descriptive entries, a KWIC or KWAC subject index could readily be prepared. Most of the entries are particularly suitable for this type of indexing. The branch of the Department of Education and Science which produces the publication, OSTI, should be in a position to organize such an index and would gain a practical stake in automated index production.

$$
\text { Yours, etc., }
$$

\section{Peter Brown,} Secretary.

British Nutrition Foundation Ltd,

Alembic House,

93 Albert Embankment,

London SE1.

\section{On the Science of Science}

SIR,--In your editorial "The Magic of Numbers" (Nature, 217,$793 ; 1968$ ) and in the letter of Gennadi Dobrov and Alan Mackay (Nature, 219, 662; 1968), important questions were raised that deserve further comment. Taking issue with Professor D. J. de S. Price's essay, Research on Research (Journeys in Science, University of New Mexico Press, 1967), the editorial questions the methods of the "science of science", which seem to be based on the assumption "that the part of the individual in scientific discovery is either so predictable or so negligible that it can be altogether ignored".

No competent student of the science of science would suggest that the individual is unimportant in science. 'To the editorial's question, "Can it soriously be supposed that if Archimedes, Newton and Einstein had never existed, the present state of science would no different ?" the answer is an emphatic no. The individual in science as in art is paramount. Professor Price writes that "If Beethoven had not existed, other men would have written quite different symphonies; Beethoven's private property is unmistakable". But so is Newton's and Darwin's and Einstein's. "If Planck, however, had not made his particular discovery", Professor Price continues, "somebody else would have to have made it and ... rather quickly". That may be, but without Planck physics would be different today. Another man may have made the discovery, but the total creation that was uniquely Planck's would have been lost to science. This does not mean that the scientist and his work cannot be studied in the context of his society. Government support of research, the evolution and influence of professional societies, the social origins and education of scientists, are significant elements in the growth of science, and they are being studied by historians and sociologists. Such indices as numbers of scientific journals and papers published in them or the percentage of GNP devoted to research and development do not indicate the quality of the science being done or tell anything about the working of a scientist's imagination, but they do give some measure of scientific activity relative to economic, political and social conditions. It may be, as the editorial contends, that "the science of science has far to go before it attains respectability", but the sooner we understand the factors that influence the development of science the sooner we may use science and technology more intelligently than the evidence indicates we have in the recent past.

Dobrov and Mackay ask "is it possible to characterize live scientists and real scientific institutions by quantitative indices which summarize information and illuminate key features of the system ?". The answer is surely yes, with the reservation that these indices cannot capture the illusive elements that make up so much of the personality and the creative imagination of a scientist. The historian-sociologist of science works to define and understand these elements, using whatever methods are available. If statistics will help, they should be used. For those responsible for the planning of scientific research the science of science may eventually be of great value even though, as Dobrov and Mackay note, "a broad theoretical understanding of the phenomena of science may not result. . .".

Yours, etc.,

\section{H. Fruchtbaum}

Clare Hall,

Cambridge.

Corrigendum. In the article "Rosalind Franklin and the Discovery of the Structure of DNA" by A. Klug (Nature, 219, 808; 1968) the following further corrections should be made: page 809 , column 1, lines 25-28 should read "... structure in which the orientation of the helical molecules in the unit cell of the crystal is analysed and a detailed picture of the arrangement of the phosphate groups is proposed"; page 843 , column 1 , line 66 , "chains are" should read "chains appear to be"; page 843, column 2, lines 17-18, should read ". . . data made it possible to propose an orientation for the holical molecule ..."; the last line of the legend to Fig. 2 should read "Drawing adapted from ref. 9 which is based on the 1953 models".

ConRigendum. In the article "Formation of Dimer Cations of Aromatic Hydrocarbons" by B. Badger and B. Brocklehurst (Nature, 219,$263 ; 1968$ ), values of $K$ for excimers (the excimer/monomer fluoresconce ratio) were mistaken for $K_{e}$ (the equilibrium constant) in quoting from references 5, 6 and 7 . The order of magnitude of the values calculated for dimer cations and tho qualitative conclusions are not affected. 